\title{
A case study report on Spondylosis (Asthimajjagat Vata)
}

\author{
Case Report
}

\section{Abhijit Dinkarrao Shekhar1*, Mayur Shiralkar²}

\section{PhD (Scholar) and Assistant Professor, Department of Kayachikitsa,}

2. Professor and HOD, Department of Shalakya Tantra,

Dr.D.Y. Patil College of Ayurved and Research Center, Dr.D.Y. Patil Vidyapeeth (Deemed to be University) Pimpri, Pune.

\begin{abstract}
Spondylosis is one of the commonest forms of joint disorder. Mostly it comes under concept of Vatavyadhi which mainly occurs due to vitiated vat dosha which is due to dhatukshaya (1) Basically this disease involves asthi and majja dhatu. This disease limits our daily activities such as walking, running, gait up, dressing, cycling, bathing etc.which makes patient disabled or handicapped. It is a kashtasadhya vatavyadhi due to intensive pain and restricted movements of joints. Here we discuss a case report of asthimajjgat vatavyaddhi which is best treated by ayurvedic concepts which was described by acharyas in vatvyadhi chikitsa adhyaya.
\end{abstract}

Key Words: Spondylosis, Vatavyadhi, Asthimajjagata Vata, Kashtasadhya.

\section{Introduction}

Ayurveda is an holistic science of life and also the oldest and greatest surviving medical system in the world. It is based on various true principles. One of the important is Tridosha siddhanta under which a number of diseases are described in samhita granthas. Vatavyadhi is one of the important vyadhi which occurs due to vitiated vata dosha.(2) Followed by this pitta and kapha dosha plays important role in pathogenesis of disease development. Without vata dosha pitta and kapha dosha are helpless. Due to various causative factors in aahara, vihara vata dosha gets vitiated which obstructs various channels (srotasa) inside the body and results into development of two types diseases, one is dhatukshayatmaska vatavyadhi and margavarodhjanya vatavyadhi. Asthi-majjagata vata is one of them which is due asthi-majja kshay. Nirupasatambhit vata is the one of causative factor for dhatukshayatmaka vatavyadhi(3). Spondylosis a painful condition of the spine resulting from the degeneration of the intervertebral discs.occurs at different levels i.e. cervical, thoracic and spinal. It become severe when there is compression of nerve roots with subsequent sensory as well as motor disturbances which leads as pain, numbness and paresthesis, tingling and numbness, muscle weakness in the extremities \& then radiculopathy.(4) When cervical vertebrae involved it is as called cervical spondylosis \& lumber region verterbrae involved called lumbar spondylosis.

\section{* Corresponding Author:}

\section{Abhijit Dinkarrao Shekhar}

$\mathrm{PhD}$ (Scholar) \& Assistant Professor, Department of Kayachikitsa, Dr.D.Y. Patil College of Ayurved and Research Center, Pimpri, Pune -18 of Dr.D.Y. Patil Vidyapeeth, Pune (Deemed to be University). India Email Id: abhijitshekhar00@gmail.com

\section{Case report}

A 50 years old female house wife, patient presented with complaints of bilateral upper limb \& lower limb tingling and numbness sensation, difficult and painful joint movements since two years, loss of appetite since two months and intermittent constipation. She had no history of any major illness like Diabetes Mellitus/Hypertension/ Ischemic Heart Disease/Epilepsy/ Malaria/Typhoid/ Jaundice/ Blood Transfusion/ Drug allergy.In surgical history there is no any major operative in past. In obstetric history she had two children with normal delivery, G1Male-45 years,G2-Female-40 years, In gynecological history she was menopause. For above complaints she consulted with orthopaedic and stared with allopathic medicines Tab Enzoflam One in thrice in a day, Tab Gabapentin one in twice in a day,Cap Sompraz D one in day on empty stomach, Tab Calcium one in day with milk, Tab Alprax $0.25 \mathrm{mg}$ SOS, Inj Vit D deep intramuscular once in a week, Inj Meganeuron intramuscular alternate day, Rhumacare oil for daily for massage. After taking this allopathic treatment she relived in pain and other symptoms but when stops the above symptoms gradually worsen so for reliving from above symptoms she consulted in Ayurvedic college. On Examination- her vitals were, Pulse- 78/min, regular, Blood Pressure- 130/68 mm of Hg Temp-980F, There was no Pallor/ Cyanosis/ Clubbing/ Icterus/ Lymphadenopathy, her JVP was within normal limit. In Systemic Examination-Respiratory System showed clear bilateral air entry, No adventitious sounds, no deformity in chest was found, Cardiovascular system examination showed first sound (S1) and second heart sound (S2) normal, No murmurs were audible, Per abdominal examination found soft, non tender abdomen in all quadrants, bowel sounds were normal. In neurological examination she was well conscious, well oriented, obeys verbal commands, pupils-B/L normal size reacting to light, her planters reflexes in Right \& Left extremities shows flexor response. 
Table 1: In Reflexes examination

\begin{tabular}{c|c|c|c|c|c|} 
Extremity & $\begin{array}{c}\text { Biceps } \\
\text { Jerk }\end{array}$ & $\begin{array}{c}\text { Triceps } \\
\text { Jerk }\end{array}$ & $\begin{array}{c}\text { Supinator } \\
\text { Jerk }\end{array}$ & $\begin{array}{c}\text { Knee } \\
\text { Jerk }\end{array}$ & $\begin{array}{c}\text { Ankle } \\
\text { Jerk }\end{array}$ \\
\hline Right & ++ & ++ & ++ & ++ & ++ \\
\hline Left & ++ & +++ & ++ & +++ & ++ \\
\hline
\end{tabular}

(++ - Normal, +++ -Exaggerated )

Neck stiffness was present, Babinski signnegative, while sensory system of joints examination for pain, touch, temperature was within normal limit.

\section{Ashtavidha pariksha(5)}

- Nadi-78/min, regular (Vata-Pita Pradhanta),

- Druk-Dina

- Mala- Asmayak intermittent hard stool with tendency of straining

- Akruti-Krusha,(lean)

- Mutra- Samyak approximately 5-6 times/ day, pale yellow in colour

- Sparsha-Ruksha (dry)

- Jivha- Niram

- Dushta Strotas parikshan-

- Asthivaha Strotas- Asthi-sandhi shool (joint pain), balakshaya, angamarda (body pain), daurbalya (generalized weakness)

- Majjavaha Strotas- Aswapna (no dreams), stabdhata, asthiruja (bone pain), Asthi saushirya (osteoporosis)

- Purishvaha strotas - Asmayak malapravritti, malavshtambha intermittently (constipation)

Table 2: Local examination of joints

\section{Joint Name Right Knee joint Left Knee joint}

Local temperature Slightly raised Slightly raised

\begin{tabular}{|c|c|c|}
\hline & & \\
\hline Swelling & No & No \\
\hline Crepitation & 3 & 4 \\
\hline Redness(Rubor) & No & No \\
\hline Fluid & No & No \\
\hline Angle of flexion & 35 & 30 \\
\hline \multirow{2}{*}{ Angle of extention } & 140 & 160 \\
\hline & Right Elbow & Left elbow \\
\hline Angle of Flexion & Full & Full \\
\hline Angle of extension & 140 & 150 \\
\hline Palmer grip & $\begin{array}{l}\text { Present with } \\
\text { normal }\end{array}$ & $\begin{array}{l}\text { Present with } \\
\text { normal }\end{array}$ \\
\hline \multicolumn{3}{|c|}{$\begin{array}{l}\text { Cervical Joint } \\
\text { Inspection }\end{array}$} \\
\hline \multirow{2}{*}{\multicolumn{2}{|c|}{$\begin{array}{l}\text { Alignment in sagittal and coronal plane } \\
\text { (e.g., kyphotic cervical spine) } \\
\text { Prior surgical scars (e.g., prior ulnar } \\
\text { nerve transposition or carpal tunnel } \\
\text { surgery) }\end{array}$}} & No \\
\hline & & No \\
\hline \multicolumn{2}{|c|}{$\begin{array}{l}\text { Muscle atrophy (e.g., palsy will see } \\
\text { decrease deltoid and biceps mass) }\end{array}$} & No \\
\hline
\end{tabular}

\section{Palpation}

Local tenderness on the spinal axis

Present

Asymmetric

No

Flexion

Extension

Rotation

Lateral bend

\begin{tabular}{|c|c|c|}
\hline \multicolumn{3}{|c|}{ Motor Examination } \\
\hline Primary motion & Primary muscle & $\begin{array}{c}\text { Innervation and } \\
\text { nerve root } \\
\text { involment }\end{array}$ \\
\hline $\begin{array}{l}\text { Scapular } \\
\text { stabilization }\end{array}$ & Serratus muscle & $\begin{array}{l}\text { Long thoracic } \\
\text { nerve (C4)-mild } \\
\text { involvement }\end{array}$ \\
\hline Shoulder abduction & Deltoid muscle & $\begin{array}{l}\text { Axillary nerve- } \\
\text { mild involvement }\end{array}$ \\
\hline $\begin{array}{l}\text { Shoulder internal } \\
\text { rotation }\end{array}$ & $\begin{array}{l}\text { Subscapularis } \\
\text { muscle }\end{array}$ & $\begin{array}{l}\text { Subscapular nerve- } \\
\text { mild involvement }\end{array}$ \\
\hline $\begin{array}{l}\text { Shoulder external } \\
\text { rotation }\end{array}$ & $\begin{array}{l}\text { Infraspinatus } \\
\text { muscle }\end{array}$ & $\begin{array}{l}\text { Suprascapular } \\
\text { nerve- mild } \\
\text { involvement }\end{array}$ \\
\hline $\begin{array}{l}\text { Elbow flexion } \\
\text { (palm up) }\end{array}$ & $\begin{array}{l}\text { Biceps \& } \\
\text { brachialis muscle }\end{array}$ & $\begin{array}{l}\text { Musculocutaneous } \\
\text { nerve- mild } \\
\text { involvement }\end{array}$ \\
\hline $\begin{array}{l}\text { Elbow flexion } \\
\text { (thumb up) }\end{array}$ & $\begin{array}{l}\text { Brachioradialis } \\
\text { muscle }\end{array}$ & $\begin{array}{l}\text { Radial nerve- } \\
\text { Moderate } \\
\text { involvement }\end{array}$ \\
\hline Wrist extension & $\begin{array}{l}\text { Extensor carpi } \\
\text { radialis longus } \\
\text { muscle }\end{array}$ & $\begin{array}{l}\text { Radial nerve- } \\
\text { Moderate } \\
\text { involvement }\end{array}$ \\
\hline Wrist supination & Supinator muscle & $\begin{array}{l}\text { Deep branch } \\
\text { Radial nerve- } \\
\text { Moderate } \\
\text { involvement }\end{array}$ \\
\hline Elbow extension & Triceps muscle & $\begin{array}{l}\text { Radial nerve- } \\
\text { Moderate } \\
\text { involvement }\end{array}$ \\
\hline Wrist flexion & $\begin{array}{l}\text { Flexor carpi } \\
\text { radialis \& Planter } \\
\text { nevre }\end{array}$ & $\begin{array}{l}\text { Median nerve- } \\
\text { Moderate } \\
\text { involvement }\end{array}$ \\
\hline Wrist pronation & $\begin{array}{l}\text { Flexor pollicis } \\
\text { longus, and } \\
\text { Pronator quadratus. }\end{array}$ & $\begin{array}{l}\text { Median nerve- } \\
\text { Moderate } \\
\text { involvement }\end{array}$ \\
\hline DIP Finger & $\begin{array}{l}\text { Flexor digitorum } \\
\text { profundus }\end{array}$ & $\begin{array}{l}\text { Ulnar nerve \& } \\
\text { Anterior } \\
\text { interosseous nerve } \\
\text { - Moderate } \\
\text { involvement }\end{array}$ \\
\hline Thumb extension & $\begin{array}{l}\text { Extensor pollicis } \\
\text { longus muscle }\end{array}$ & $\begin{array}{l}\text { Posterior } \\
\text { interosseous nerve } \\
\text { - Moderate } \\
\text { involvement }\end{array}$ \\
\hline Finger abduction & Interossei muscle & $\begin{array}{l}\text { Deep branch ulnar } \\
\text { nerve- Moderate } \\
\text { involvement. }\end{array}$ \\
\hline & Sensory system & \\
\hline Touch & & \\
\hline Temperature & & Within normal Limi \\
\hline Pain & & \\
\hline & & \\
\hline $\begin{array}{l}\text { Flexion } \\
\text { Extension }\end{array}$ & & $\begin{array}{l}\text { Unable to perform } \\
5-6 \text { degree }\end{array}$ \\
\hline Lateral Flexion & & 20-30 degree \\
\hline Sensory system & & \\
\hline & uch & \\
\hline Tem & $\begin{array}{l}\text { erature } \\
\text { ain }\end{array}$ & \\
\hline
\end{tabular}

\section{Xray cervical spine}

Loss of curvature of cervical spine with degenerative changes at $\mathrm{C} 1-\mathrm{C} 7$ vertebra. 


\section{Xray lumbar spine}

Loss of curvatures of lumbar vertebrae with lordosis and degenerative changes. Osteoporosis of lumbar vertebras.

\section{MRI Spine-}

Loss of cervical lordosis. Diffuse bulging is seen at level of C3-C4 intervertebral disc resulting into cervical cord compression with posterior thickening if longitudinal ligament. There is deformity notes at dorsal spine where convexity present at right side. At the level of D3-D6 ligamentum flvam hypertrophy is noted. Lumbar lordosis is noted with bulging and desiccation at L1-L4 levels.

\section{Laboratory Investigations}

HMG- Hb- 12.4, WBC-4305, PLT-164000, ESR-28 BSL-F-80, PP-110, Rheumatic factor (RA)Negative Sr. calcium -12, Urine Examination WNL,ASO titre-Negative, Uric acid level-5.0,ECG Sinus Rthym.

With all above investigations Diagnosis (Vyadhi nidan) was made as Cervical and Lumbar Spondylosis with degenerative changes while in point view of ayurved diagnosis was made as Asthimajjgata vata.

\section{Nidan panchak}

a) Hetu (causes)-Considering point of sannikrishta hetus (causes) threre is excess lifting of things, ruksha ahar (d ry food), excess chankraman,ativyayam, Various bad postural habits in sitting, similarly in viprakrushta hetusvardhakya (old age) is primarily considered.

b) Purvaroop-Started with tingling and numbness in all extremities

c) Roop (symptoms)-generalized weakness, difficult in gait, joints of all extremities become stiff, pain

\section{d) Samprapti (pathogenesis)}

Figure 1: Showing the samprapti

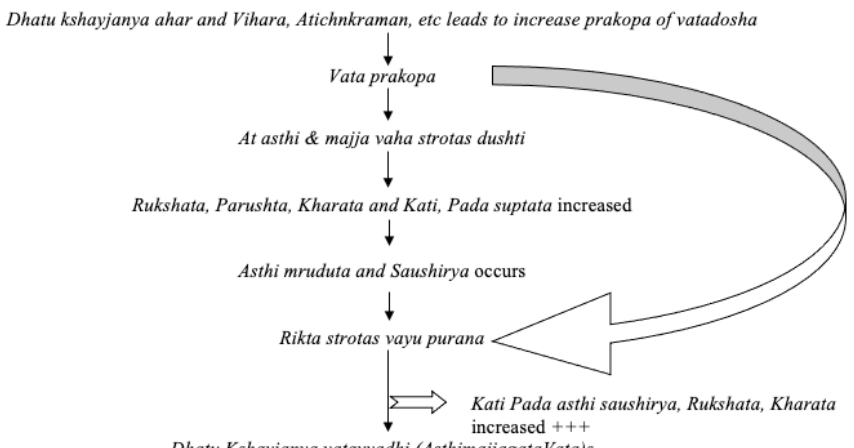

Dhatu Kshayjanya vatavyadhi (AsthimajiagataVatajs

e) Treatment and outcome (Chikitsa)

As per Samprapti of dhatukshayjanya vatavadhi i.e.asthimajjagat vata (spondylosis) is due to asthi saushirya (osteoporosis). Which is due to sarakta majja kshay due to vitiated vata ${ }^{l}$ So as per etiopathogensis (samprapti) the asthivaha strotas \& vat vrudhi are important factors so in the plan of treatment, So treatment plan is divided in two parts 1) Shodhan chikitsa2)Shaman chikitsa for 3 weeks
Shodhan Chikitsa

- Snehan - Bala ashwagandha taila + Mahamash tail

- Swedan- Pinda sweda with shalishastikTandul

- Basti- Anuwasan and Niruha basti Vyatyasat A/N/A/ N/A/N/A followed by

- Panchatiktak kshirabasti-total $230 \mathrm{ml}$

\section{Shaman Chikitsa}

- Mahayograj guggulu(5) 250mg 2 thrice in day ds before food, Ashwagandha ghanavati 250mg 2 tablets thrice in day before food,

- Vatahar yog 3gm+Eranda sneha $10 \mathrm{ml}$ nisha kala(at night),

- Shatavaryadi ghrita $30 \mathrm{ml}$ on empty stomach,

- Baladi kshirapaka $30 \mathrm{ml}$ twice in day before food

Lepa-dashang lepa in day time.

Pathya

- Avoid casutive factors

- Aharaj- Snigdha, madhur rasatmak, guru anna sevan, mug dal,ghrita, dugdh, luke warm water,

- Viharaj-,Excess travelling, No lifting of heavy weight, divaswap, proper sleep in night.

Table 3: Treatment result

\begin{tabular}{|l|l|l|l|l|} 
Observation At First & 1st wk & 2nd wk & 3rd wk \\
day
\end{tabular}

\begin{tabular}{|c|c|c|c|c|}
\hline \multirow{2}{*}{\multicolumn{5}{|c|}{ SLR Test }} \\
\hline & & & & \\
\hline Left Leg & 50 & 70 & 80 & 80 \\
\hline Both limbs & 30 & 35 & 40 & 60 \\
\hline Knee joint & Right & Left & Right & Left \\
\hline $\begin{array}{l}\text { Angle of } \\
\text { flexion. }\end{array}$ & 40 & 40 & 40 & 30 \\
\hline $\begin{array}{l}\text { Angle of } \\
\text { Extion. }\end{array}$ & 160 & 160 & 160 & 160 \\
\hline Elbow joint & Right & Left & Right & Left \\
\hline $\begin{array}{l}\text { Angle of } \\
\text { flexion. }\end{array}$ & full & full & full & full \\
\hline $\begin{array}{l}\text { Angle of } \\
\text { Extension. }\end{array}$ & 150 & 150 & 150 & 150 \\
\hline Walk & $\begin{array}{l}\text { Painful } \\
\text { and } \\
\text { restricted } \\
\text { to walk }\end{array}$ & $\begin{array}{c}\text { Able } \\
\text { walk, } \\
\text { Joints } \\
\text { Movemen } \\
\text { ts slightly } \\
\text { improved } \\
\text { with } \\
\text { decreasing } \\
\text { pain }\end{array}$ & $\begin{array}{c}\text { Stand with } \\
\text { support } \\
\text { Walk } \\
\text { improved } \\
\text { Pain } \\
\text { decreased } \\
\text { significant } \\
\text { ly }\end{array}$ & $\begin{array}{l}\text { Walk with } \\
\text { help of } \\
\text { walker }\end{array}$ \\
\hline
\end{tabular}

Cervical Joints/Lumbar Joints

Tingling and

Numbness

Pain

Stiffness

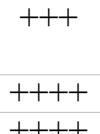

$++$

\begin{tabular}{|c|c|}
\hline+ & + \\
\hline+ & + \\
\hline++ & + \\
\hline
\end{tabular}

Movements Painless improvement

$(+++)=$ Severe pain, $(++)=$ Moderate pain, $(+)=$ Mild pain

\section{Discussion}

Number of patients suffering from asthimaijagatavata is quite high because of today's life style. In ayurveda asthimajjagatvata is described under 
heading of vatavyadhi and any type of pain cannot be present without presence of vatadosha.In present case scenario the action of drugs is as follows

- Bala Ashwagandha Tail (7) - One of favorite herbo mineral combination of oil which is used as external massage application which helps in pacifying for vitiated vata dosha lakshans, The base for this oil is blend which helps promote muscle strength and support to develop muscle tone. The combination of herbs helps is nourishing for the muscles and tissues of bones i.e.osteoporosis. While bala herbs helps to support energy and the nervous system, also calms the nerves and pacifies vata dosha which helps in reducing the dhatukshayajnya lakshans of vatavyadhi.

- Mahamash Taila (8) - It is a very powerful oil used for various neurological condition including peripheral nervous system.Masha means black gram the important ingrident of this oil.his oil is helpful in reducing pain of multiple joints which is due to vitiated vata dosha in this oil the herbs are basically prepared in seasame oil with kwath i.e. decoction then the solid waste thrown out and remaining oil contains only oil base as well water base phytoactive principles of the herbs. After application of this oil over the skin and joint helps in reducing the symptoms if sandhishoola, graha(stiffness), which is due to vitiated vata dosha can easily pacifies and strengthen the tissues and muscle.

- Pinda Sweda with shalishastik tandul - It is one of the famous type of swedan for vatavyadhi.chikitsa. In pinda sweda it contains Shali (i.e.rice) which is boiled. It is used in the form of pinda and packed in piece of cloth. Then herbomineral preparation of decoction is prepared with milk then swedan was given over all body which helps in reducing the vitiated vata dosha gunas like rukhsa,laghu, chala sheeta guna and improves the muscle strength as well as reduces pain of lumbar as cervical region joints. It also increases the tone muscles and nutrition of muscles related with joints.

- Basti - Basti or enema is one of the best treatment in Vatavyadhi(1).In Asthi majjagata vata diseases chikitsa here we used anuvasan basti with Dashamoola taila in $60 \mathrm{ml}$ and niruha basti $960 \mathrm{ml}$ in alternate days for 11 days which acts as vatanuloman karma from intestine relieves constipation and helps in apan vayu for its proper adhogati and karma and then started with Panchatiktak basti $260 \mathrm{ml}$ which for 10 days. Panchatiktak basti contains kantakari, nimb, patol, guduchi, vasa herbs which are all of tikta,katu rasa(taste) dravyas, and ushna veerya (potency) \& after preparation of this decoction with milk it forms kshirpak with addition of ghrita after giving enema for in intestine it pacifies the vatadosha lakshanas and do vatashaman karma. The tikta guna of drvyas acts as pachan karma and as well as dhatvagni vardhan karma which increases asthi dhatvagni and helps in generation of good forms of asthi dhatu and that stops asthi kshay(osteoporosis).Also the sneha that means milk and ghrita also do vatashaman karma due to its intellectual properties and do bruhan karma of asthi dhatu.

- Mahayogaraja guggulu (9) - It is a very famous classical medicine used in relieving symptoms of various vyadhi (diseases) caused by vitiated vata dosha,specifically those which are associated with severe depletion of body tissues that is called ad dhatu kshaya and due to its balya properties that means strength promoting and rasayana effects (rejuvenating).

- Vatahar yoga with erand sneha - Vatahar yoga is best yoga which contains rasna eranda, amrita, ashwagandha, balamula, punarnava, gokshu, shatavari shunthi,. This comnation of herbomineral preparation with errand sneha acts as snhayukta virechana. (purgation) which do vatanuloman and purish shodhan karma and helps in pacifying the vitiated vata dosha.

- Shatavaryadi ghruta - It contains shatavari, jivaniya gana,bala,rasna etc. which acts as good quality of balya as well as brihan and vata shamak which helps in samprati vighantan.

- Baladi kshirpaka - Bala,rasna,eranda ashvagandha, guduchi,shatavari, masha,devdaras are used in the preparation of kshirpaka which help us in the maintenance of mansa \& asthi dhatu. so They pacifies vata vrudhi \& do bruhan karma of asthi dhatu.

In this way after using this regimen as per suggested by acharya, in third week we found excellent result in decreasing symptoms of Spondylosis (asthmaijagata vata.) Patient got excellent result in their joint problems along with improvements.

\section{Conclusion}

Ayurveda treatment in the form of shodhana shaman, and internal medicines is a good alternative option in the management of such painful condition.

\section{References}

1. Agnivesa,Charaka Samhita, 4th ed. Varanasi: Chaukhambha Sanskrit Sansthan; 1994. (Kasi Sanskrit series 228), Chikitsa 28/16-20

2. Yadavji Trikamji Acharya, Charaksahita by Agnivesa revised by Charak \& Dhrudhabala with Ayurved adipeeka commentary of Chakrapanidatta (2007 reprint edition) Varanasi, Chaukhamba Prakashan.

3. Pandit Hari Sadashiv Shastri Paradakar, Astang ahrday of Vagbhata with the Commentaries, Sarvangasundara of Arundatta and Ayurved arasayan of Hemadri (2007 Reprint Edition) Varanasi ,Chaukhamba Surbharati Prakashan)

4. Ralston, Stuart H., Ian D. Penman, Mark W. J. Strachan, and Richard Hobson, eds. 2018. Davidson's Principles and Practice of Medicine. 23rd ed.Edition: 23, City of publication: London, EnglandEditor(s): Stuart H. 
Ralston, Ian D. Penman, M. Year of publication: 2018

5. Tekade Anand1*, Watkar Deepali2, Daulatkar Kavita3, Dive Mukund4* REVIEW OF ASHTAVIDHA PARIKSHA W.S.R. TO NADI PARIKSHA, International Journal of Ayurveda and Pharma Research, ISSN: 2322 - 0902 (P) ISSN: 2322 - 0910 (O), http://ijapr.in

6. Chunekar K.C,Bhavaprakasha Nighantu of Shri Bhavmishra, Varanasi, Chaukhamba Bharti Academy,2006-Reprint Edi
7. https://www.banyanbotanicals.com/info/blog-thebanyan-insight/details/ashwagandha-bala-oil/

8. Vaidya LC, editor, (8th ed). Bhaishajya Ratnavali of Govindadas, Aamavata Adhikar. New Delhi: Motilal Banarasidas, 2002; 389.

9. Murthy KR ,Sharangadhara samhita Madhyama khanda Varanasi.Chaukhamba orientalia -eddition reprent 7/56-69P.

10. https://www.ayurmedinfo.com/2012/06/11/ balaswagandhadi-thailam-benefits-how-to-useingredients-sidse-effects/ 